\title{
Female Entrepreneurship And Economic Growth: An Institutional Theory Analysis
}

\author{
Ansar Waseem \\ School of Business \& Economics \\ University of Management \& Technology, Lahore
}

\begin{abstract}
Women are untapped resources for economic growth. Female entrepreneurs, like their male counterparts, can boast the economic growth of a country. Women owned business creates jobs which results in poverty alleviation and eradication of unemployment. Similarly, women entrepreneurs add diversity to the entrepreneurial mix of a country. Female entrepreneurs intensify competition through creativity and innovation. However, the institutional profile and overall business environment of any country have significant role in women business start-ups. This study attempts to provide a plausible account on how women entrepreneurs increase economic development of a country. It is proposed that women entrepreneurs enhance the national competitiveness level which leads to rapid economic growth. Moreover, the relationship between female entrepreneurship and national competiveness level is moderated by overall business environment of the country. To test this framework, data was collected from different sources. The results of regression analysis support the research hypotheses.
\end{abstract}

Keywords: Female Entrepreneurship; Economic Growth; National Competitiveness; Institutional Profile; Business Environment.

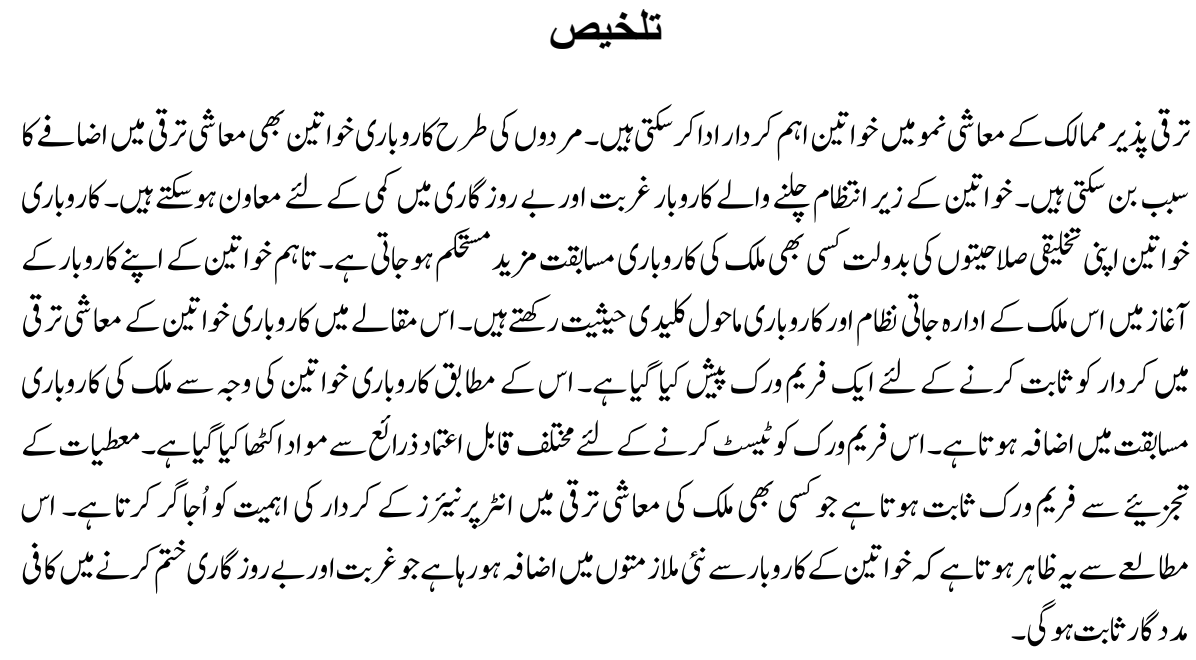

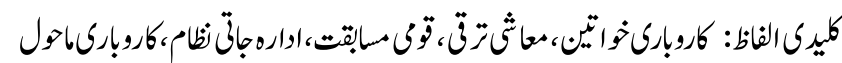




\section{Introduction}

Active participation of women in economic activities is necessary for development of any country (Sarfaraz, Faghih \& Majd, 2014). Countries with low participation of women are characterized by under utilization of the resource which has profound effect on their economic growth (Albotmeh \& Irsheid, 2013). Among these activities, entrepreneurial initiatives have significant effect on the economic development of a country, and women entrepreneurs are major contributor to this growth (Goltz, Buche \& Pathak, 2015). In the past, entrepreneurship was considered to be male dominated; but now researchers, policy makers and overall population is giving due attention to female entrepreneurs (Ramadani et al., 2015). Now, female owned businesses are expanding in all countries. Women are considered to be fast growing entrepreneurial population (Nguyen, Frederick \& Nguyen, 2014). According to Global Entrepreneurship Monitor, around 25\% to 35\% companies in the formal sector are owned by women (Estrin \& Mickiewicz, 2011). Inspite this, the share of female entrepreneurs is far less than their male counterparts (Hattab, 2012) and this trend is prevalent worldwide.

Women entrepreneurs are considered to be important for economic growth of any country. This is more relevant for low income level countries where majority of micro-enterprises are owned and operated by women (Palanivelu \& Jahan, 2014). Entrepreneurs create new business which results in more jobs, thus reducing unemployment (Okah-Efogo \& Timba, 2015). According to knowledge based view of the firms, entrepreneurs relies more on the human capital to achieve sustainable competitive advantage rather than the accumulation of physical factors of production. Female entrepreneurs are not exception. Much like their male counter parts, they innovate. New business endeavours promote competition through innovation (Colombelli, Krafft \& Vivarelli, 2016). Entrepreneurs intensify the competition by encouraging new entrants and upgrading/developing existing technologies. Literature shows that there are two ways that innovation can lead to economic growth. First is technological competitiveness which involves development of new products and services; the second is cost competitiveness which entails replacement of human capital with traditional factors of production (Petrariu, Bumbac \& Ciobanu, 2013). Therefore, new business ventures result in fostering economic development through competition and innovation (Llussa, 2009).

Despite the fact the women entrepreneurship is on rise, women entrepreneurs operate in low growth sectors. Due to many individual, socio-cultural and economic constraints, female entrepreneurs are limited to micro-enterprises (Welter, 2004). A growing body of research is focusing on the role of institutions on the growth of entrepreneurship among females (Terjesen \& Amoros, 2010). Creation of new business ventures is dependent upon the overall environment (Minniti \& Nardone, 2007). Likewise, any country's business infrastructure is the core facilitating factor in growth of business (Marques, 
2017). A number of country level factors such as lack of access finance, regulatory issues, and confinement to low growth sections result in less participation of women in entrepreneurial activities. Females face considerable issues in raising capitals. This becomes importance for the success of their ventures because female have very less saving of their own (Danish \& Smith, 2012) and they also receive very little support from their family. Regulatory and financial institutions are important for business activities as they directly and indirectly affect the demand and supply of entrepreneurs. Therefore, whether entrepreneurial initiatives are productive, non-productive or even destructive depends upon the development of institutions (Acs et al., 2011). Given the importance of institutions, female entrepreneurial activities are closely related with the institutional system of a country (Verheul, Stel \& Thurik, 2006).

An over whelming amount of literature concurs that entrepreneurship boasts economic growth. However, the role of entrepreneurship in economic growth is still underestimated (Acs et al., 2011). "Although it is widely acknowledged that entrepreneurship is an important force shaping the changes in the economic landscape, our understanding of the relationship between entrepreneurship and development is still far from complete" (GEM 2008 Executive Report, cited in Sarfaraz, Faghih \& Majd, 2014). The studies exploring the relationship between entrepreneurship and economy activities are limited to firm level and very few have considered the aggregated or national level (Dejardin, 2011; Kobeissi, 2010). This study aims to provide a plausible account of causal relationship between entrepreneurial activities of women and economic growth by using data at national level. Moreover, scholars have limited understanding on how business ventures are more successful in one country as compared to others (Busenitz, Gomez \& Spencer, 2000). This is because literature of female entrepreneurship has given more attention to individual factors as compared to social and collective environment (Lock \& Smith, 2016); and legal and business environment are seldom discussed (Ahl, 2006). Most of the research of female entrepreneurship has focused on the availability of credit and financial institutes; while the role of other institutions has been overlooked (Terrell \& Troilo, 2010). It is proposed that the variation in the rate of entrepreneurial activities especially among women can be explained through the national competition level, overall business environment and institutional system.

Goncalves et al., (2015) note that due to mathematical restrictions of their model, neoclassical economists have neglected the role of entrepreneurs in the national economic growth. Given the importance of female entrepreneurship in economic growth of a country, this study aims to fill the gap in research by focusing on female entrepreneurship and economic growth in global context. This study will contribute to the extant literature on female entrepreneurship and economic growth in three ways; first the importance of female entrepreneurship and its effect on growth of business competitiveness is highlighted; second by emphasizing how business environment can lead to competition 
among firms operating in a country; third, by asserting the importance of female entrepreneurship and business friendly policies in economic growth of a country.

This study deals with the basic question: how opportunities of entrepreneurial activities for women in a country can lead to its economic growth. This study uses institutional theory since it is particularly suitable to analyze national context for entrepreneurship (Baughn, Chua, \& Neupert, 2006) as institutions shapes the entrepreneurial decisions (Naguib \& Jamali, 2015). This framework allows observing the effect of opportunity driven female entrepreneurship and a supportive business environment in enhancing national competitiveness which can in turn leads to rapid economic growth. This is in line with observation of Acs et al., (2011) that the nexus between entrepreneurial activities, institutional conditions and economic growth may be considered while studying entrepreneurship in a country. This study also take into consideration the interaction between different levels as Wennekers and Thurik (1999) note that "linking entrepreneurship to economic growth also means linking the individual level to the firm and the macro level."

\section{Literature Review \\ Female Entrepreneurship and National Competitiveness}

The role of entrepreneurs in boasting economic performance of a country can be assess through the introduction of new product and services, and growth in technological innovation (Goncalves et al., 2015). An entrepreneur is regarded as an innovator and risk taker, who promotes economic development through competition and introduction of new technology (Gries \& Naude, 2011). He or she can spot an opportunity which others fail to notice the same (Palanivelu \& Jahan, 2014). The technological innovation promotes a healthy competition between the firms which results in either lower cost or better quality of product. Entrepreneurship is generally regarded as a positive phenomenon (Colombelli, Krafft \& Vivarelli, 2016). This is because creation of new business ventures intensifies the competition (Hilman \& Warokka, 2014).

The greatest proponent of role of entrepreneurs in fostering competition is Schumpeter. His notion of 'creative destruction' elaborates his claims that entrepreneurs introduce new technologies and innovations in the market which gradually replace old and inefficient ones (Goncalves et al., 2015); thereby not only encouraging the participation of new entrant but also facilitating development of existing firms. Thus, development of new products and services encourage people to invest more in technological innovation, leading to a stiffer competition at national level (Petrariu, Bumbac \& Ciobanu, 2013)

Female entrepreneurs just like their male counterparts also intensify competition between firms operating in same market. Female entrepreneurs add diversity to the economic 
activities in the country (Verheul, Stel \& Thurik, 2006). Female owned businesses are a source of productivity and they encourage the development of new business (Nguyen, Frederick \& Nguyen, 2014). This leads to a greater competition between firms. This study considers the role of opportunity driven entrepreneurship among female is defined as "which is an active choice to start a new enterprise based on the perception that an unexploited or underexploited business opportunity exists" (Acs, 2006). This type of female entrepreneurship contributes more towards innovation and competition as compared to the necessity based entrepreneurship because they can easily identify and exploit an economic opportunity (Palanivelu \& Jahan, 2014).

Based on above discussion, our first hypothesis is given below:

\section{Hypothesis No 1:}

Opportunity driven female entrepreneurship intensifies national competitiveness.

\section{Moderating Role of Business Environment on the Relation between Female Entrepreneurship and National Competitiveness}

Cultural and legal environment of a country have profound effect on the level of entrepreneurial activities taking place in it (Baughn, Chua, \& Neupert, 2006). Institutions can be categorized differently. For instance, in his seminal work, North (1990) has distinguished between two types of institutes: formal and informal. Formal institutes provide a regulatory environment in the form of laws, rules and governmental procedures where business operates (Pulido, Jimenez \& Noguera, 2014). These formal institutions promote business by reducing transaction cost (Estrin \& Mickiewicz, 2011). Both formal and informal institutes are helpful in the promotion of quality as well as quantity of female owned business (Terjesen \& Amoros, 2010). Formal institutes establish the 'rules of game' which can shape intentions and strategies of entrepreneurs (Goltz, Buche \& Pathak, 2015). In similar lines, Kostova (1997) has used regulatory, cognitive and normative dimensions to explain institutional profile of a country. The regulatory dimension entails laws, rules and governmental policies that provide support in launching new business, reducing risk for entrepreneurs and facilitating entrepreneurial activities (Busenitz, Gomez \& Spencer, 2000). More recently, Bates, Jackson and Johnson (2007) have proposed 3M framework (Market, Money and Management) to explain launch and growth of business endeavours. The same has been extended by Brush, De Bruin and Welter (2009) to included two more factors i.e. motherhood and meso/macro factors. These two additional factors explain the role of culture and other regulatory forces in growth of business ventures. 
Formal institutes are 'rules of the game' (North, 1990). They not only affect the extent of females entering into self employment but they also have significant influence on the type of enterprise women will own (Aidis et al., 2007). A strong regulatory environment such as regulators, institutes, economic and political pillars play an important role in flourishing entrepreneurial activities (Terjesen, Bosma \& Stam, 2016). Main function of institutes is to provide a stable mean for interaction between different actors of economy (Noguera et al., 2015). High quality of institutional support encourages entrepreneurs to pursue productive activities (Estrin \& Mickiewicz, 2011). Better legal system, business regulations, and bankruptcy laws are increases entrepreneurship (Terjesen, Bosma \& Stam, 2016). Bankruptcy laws are of particular help because of resolving insolvencies (Armour \& Cumming, 2008).

Literature shows that females entrepreneurs faces problem in raising capital for their business (Lock \& Smith, 2016) due to which their enterprise cannot flourish (Welter, 2004) or they have to wait for the launch of their business projects (Llussa, 2009). Women's firms are regarded to have lower initial capital as compared to their male counterparts and their businesses run at lower debt and equity business (Jennings \& Brush 2013). Since women mostly own firms belonging to informal sector of economy, their capital is more likely to come from informal sources (Coleman \& Carsky, 1996; Terjesen, Bosma \& Stam, 2016). Women are also prone to discriminating attitude from banks and other financial institutions (Sara \& Peter, 1998) because of issues such as prejudice or credibility (Danish \& Smith, 2012). Despite their low prosperity to bankruptcy, women have to pay more interest on loan as compared to males (Llussa, 2009). It is assumed that women are incapable of managing capital (Rubio-Bañón \& Esteban-Lloret, 2016). Therefore, women have to rely more on personal saving than men (Morris et al., 2006). The undercapitalization of female owned business results in their below-par performance. Due to their small business size and small growth sector, women have difficult relationship with financial and credit institutions (Poggesi, Mari \& De Vita, 2016). For such women, raising capital becomes a challenging job since they have less personal saving and receive little financial support from their family. Thus, access to finance becomes crucial to the success of the business especially at the start-up stage (Danish \& Smith, 2012).

Similarly, business environment has significant influence on national competitiveness. Porter (1990) has proposed a national diamond model to predict national competitiveness level of industrial countries. According to this model, government policies as well as supportive and related industries affect competiveness of a country (Kordalska \& Olczyk, 2016). A supportive institutional structure can influence the innovation activities carried out by the entrepreneurs (Busenitz, Gomez \& Spencer, 2000) which can in turn affect the competition level. Therefore, institutional profile and business environment of a country have a profound effect on both activities of female entrepreneurs as well as national competitiveness level. 


\section{Hypothesis No 2:}

The relationship between opportunity driven female entrepreneurship and national competitiveness level is moderated by business environment of a country in such a way that a better business environment will lead to more competition.

\section{Female Entrepreneurship and Economic Growth}

Social scientists have paid considerable attention in studying how entrepreneurial activities in a country leads to its economic growth. Entrepreneurship is viewed as a driver for economic development and innovation (Acs, 2006; Acs et al., 2011; Brush et al, 2006; Busenitz, Gomez \& Spencer, 2000; Dejardin, 2011; Hayton, George \& Zahra, 2002; Lock \& Smith, 2016; Korez-Vide \& Tominc, 2016; Sarfaraz, Faghih \& Majd, 2014; Stel, Carree \& Thurik, 2005; Terjesen, Bosma \& Stam, 2016; Verheul, Stel \& Thurik, 2006). Baumol (1990) holds the view that entrepreneurial activities can be productive, nonproductive and even destructive for a given economy. However, a great amount of literature concurs that entrepreneurial activities are important for economic development and growth of a country. There is consensus among researchers that entrepreneurship is the 'driving engine' of many economies (Gallant, Majumdar \& Varadarajan, 2010).

Women represent an untapped source of entrepreneurial talent (Baughn, Chua, \& Neupert, 2006; Sarfaraz, Faghih, \& Majd, 2014). Like male entrepreneurs, women entrepreneurship is regarded to be positively associated with economic growth of a country. Female entrepreneurs can help in job creation and employment generation (Noguera et al., 2015) along with reduction in gender discrimination and wages difference (Ghani, Kerr \& O'connell, 2013). On the other hand, low level of female entrepreneurship may negatively affect the economic growth of a country (Terjesen \& Amoros, 2010). Female entrepreneurship can be used as a potent tool for poverty eradication (Kobeissi, 2010). Marques (2017) notes that "women entrepreneurs may contribute to development with multiplier effects due to their greater concern for household welfare, their greater propensity to employ other women and their complementarily to overall entrepreneurship".

Previous researches have ascertained claims of scholars about the relationship between female entrepreneurship and economic development. For example, empirical work of Carree and Thurik (2003) provides valuable inside in the relationship between entrepreneurial activities and economic development of a country. Similarly, in the context of Ghana, Chamlee-Wright (2002) has found that female entrepreneurs can reduce the poverty level of a country. Okah-Efogo and Timba (2015) have found that SMEs owned by women can be used to reduce unemployment among them which leads to economic growth. It means that if proper opportunities are given to female 
entrepreneurs can contribute to their economy through job and wealth creation, poverty alleviation, innovation and enhanced national income (Brush \& Cooper, 2012; Gallant, Majumdar \& Varadarajan, 2010; Rubio-Bañón \& Esteban-Lloret, 2016).

\section{Hypothesis No 3:}

Opportunity driven entrepreneurship among women is positively associated with economic growth of a country.

\section{Mediating Role of National Competitiveness Level in the Relation between Female Entrepreneurship and Economic Growth}

There is a consensus among the scholars that entrepreneurs and competitive business environment is essential for economic development of a country (Hilman \& Warokka, 2014). Origin of these works can be rooted back to the work of Schumpeter who regarded entrepreneurship and innovation to be critical for economic growth of a society. Schumpeter regards entrepreneurs to be crucial in bringing innovation to the business sectors. According to Schumpeter (1934), entrepreneur "incessantly revolutionizes the economic structure from within, incessantly destroying the old one, incessantly creating a new one". Therefore, he emphasized the role of entrepreneurs in increasing national economic growth as their innovative capabilities intensify competition. Following this, Wennekers and Thurik (1999) argue that Schumpeterian entrepreneurs are better able to take part in economic development.

This means that dynamic and innovative organizations enhance competition in the business market. Therefore, both dynamic and static competitiveness between firms can be used as a predictor of economic growth (Schwab \& Sala-i-Martin, 2015). Female entrepreneurs make valuable contribution in technological innovation, providing employment and increasing wealth in an economy (Brush et al., 2006). Entrepreneurial activities of female are regarded to be "generator of innovation, creativity, growth and employment" (Garcia \& Capitan, 2016). The study of entrepreneurship entails identification and exploitation of an opportunity (Davidsson \& Honig, 2003). Entrepreneurship focuses on "optimization within existing mean-end framework" (Shane \& Venkataraman, 2000). Such optimization will be beneficial in removing any inefficiency in the system. Therefore, opportunity driven female entrepreneurship can lead to higher competition and an efficient economic system.

To conclude this discussion, female entrepreneurship can lead to creation of businesses, which in turn creates employment opportunities, intensifies competition between firms, support technological development, and eventually lead to a higher level of economic growth (Acs, 2006). 


\section{Hypothesis No 4:}

Competitiveness of business markets meditates the Opportunity driven entrepreneurship among women is positively associated with economic growth of a country.

Based on the above hypotheses, a conceptual framework is developed which shows the interaction between opportunity driven female entrepreneurship, business environment, national competitiveness, and economic growth.

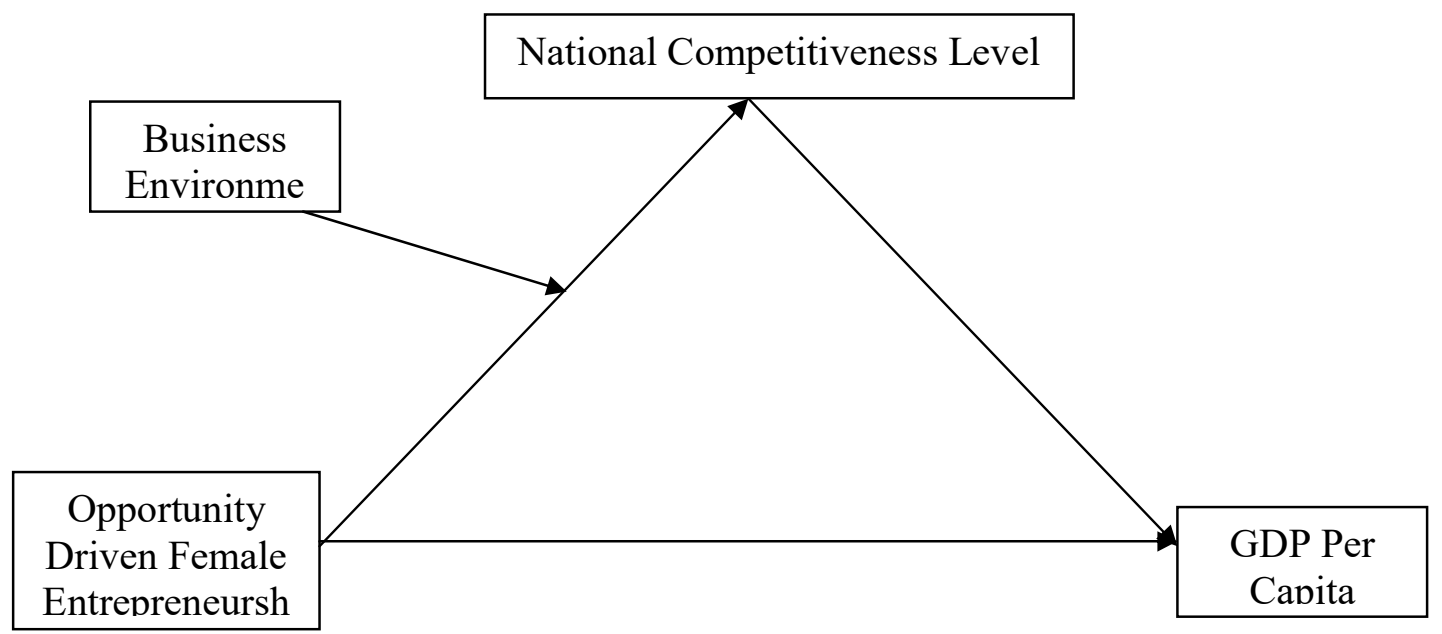

Figure No 1: Conceptual Framework

\section{Result Section}

This study aims to investigate the impact of opportunity driven female entrepreneurship and supportive business environment in increasing national competitiveness level and economic growth of a country. For this purpose, data regarding different variables involved in the study was obtained from different sources. To measure female opportunity driven entrepreneurship, data was collected from Global Entrepreneurship Monitor (GEM) which focuses on entrepreneurial activities in a country as a whole (Estrin \& Mickiewicz, 2011). Total Early Stage Entrepreneurial Activity (TEA) Index was used which measures the level of opportunities for female entrepreneurs on the basis of number of business start-ups and new ventures that are less than 3.5 years old (Hattab, 2012; Adom \& Asare-Yeboa, 2016). The overall business environment was measured from Distance of Frontier Score obtained from Doing Business Report. Data regarding competitiveness level was obtained from Global Competitiveness Index (CGI) developed by World Economic Forum as it is the most cited source and standard to measure national competitiveness (Kordalska \& Olczyk, 2016; Korez-Vide \& Tominc, 2016). Lastly, 
economic growth was measured by Gross Domestic Product per capita. Data is considered at country level following Kobeissi (2010) who notes that the literature on entrepreneurship is limited to a region or country, and studies comparing entrepreneurial practices on global level are scarce. Table No 1 shows the sources of data along with the results of descriptive statistics.

Table: 1

Descriptive Statistics of variables

\begin{tabular}{|l|l|c|c|}
\hline \multicolumn{1}{|c|}{ Name of variable } & \multicolumn{1}{|c|}{ Data Source } & Mean & $\begin{array}{c}\text { Standard } \\
\text { Deviation }\end{array}$ \\
\hline $\begin{array}{l}\text { Gross Domestic Product } \\
\text { per Capita }\end{array}$ & World Bank 2015 & $25,837.74$ & $19,849.78$ \\
\hline $\begin{array}{l}\text { Opportunity driven female } \\
\text { entrepreneurship }\end{array}$ & $\begin{array}{l}\text { Global Entrepreneurship } \\
\text { Monitor, 2015 }\end{array}$ & 69.66 & 12.13 \\
\hline Business environment & $\begin{array}{l}\text { Doing Business Report } \\
2015\end{array}$ & 69.78 & 9.36 \\
\hline $\begin{array}{l}\text { Global Competitiveness } \\
\text { Index score }\end{array}$ & $\begin{array}{l}\text { Global Competitiveness } \\
\text { Report 2015-2016 }\end{array}$ & 4.56 & 0.55 \\
\hline
\end{tabular}

Correlation between variables was checked using Pearson's correlation. Table No 2 shows the results of correlation between variables. All the variables were positively and significantly correlated with one another. Female opportunity driven entrepreneurship is positively associated with both GDP per capita and competitiveness score.

Table: 2

Correlation between variables

\begin{tabular}{|l|c|c|c|c|}
\hline Name of Variable & $\mathbf{1}$ & $\mathbf{2}$ & $\mathbf{3}$ & $\mathbf{4}$ \\
\hline Gross Domestic Product per Capita & 1 & & & \\
\hline Opportunity driven female entrepreneurship & $0.360^{* * * *}$ & 1 & & \\
\hline Business Environment & $0.769^{* * *}$ & $0.374^{* * *}$ & 1 & \\
\hline Global Competitiveness Index score & $0.688^{* * *}$ & $0.526^{* * *}$ & $0.716^{* * *}$ & 1 \\
\hline
\end{tabular}

$* * * \mathrm{p}<0.01, * * \mathrm{p}<0.05, * \mathrm{p}<0.1$, f $\mathrm{p}<0.15$

On the introduction of business environment as a moderate in the regression model, the value of $\mathrm{R}^{2}$ increases to 0.591 . Moreover, the interaction term, found by the multiplication of mean centered terms of predictor and moderator, is statistically significant in the model. 
Table: 3

Moderating role of business environment on the relationship between opportunity based female entrepreneurship and competitiveness score

\begin{tabular}{|l|c|c|c|}
\hline Name of Variable & $\begin{array}{c}\text { Unstandardized } \\
\text { Coefficient }\end{array}$ & $\mathbf{R}^{\mathbf{2}}$ & $\Delta \mathbf{R}^{\mathbf{2}}$ \\
\hline Opportunity based female & $\begin{array}{c}0.024^{* * * *} \\
(0.141)\end{array}$ & 0.277 & $0.277^{* * * *}$ \\
entrepreneurship (OE) & $\begin{array}{c}0.035^{* * *} \\
(1.267)\end{array}$ & 0.591 & $0.314^{* * *}$ \\
\hline Business environment (BP) & $\begin{array}{c}0.001^{*} \\
(0.001)\end{array}$ & 0.616 & $0.025^{*}$ \\
\hline Interaction (OE x BP) & & & \\
&
\end{tabular}

Number of Observation $=33$

In order to further ascertain the moderating role of business environment, its effect size on the relation between opportunity based female entrepreneurship and competitiveness score was calculated. Table No 4 shows that at the lower value of moderator, the relationship between the predictor and the outcome is statistically insignificant. However, the same relationship becomes significant when we move to mean and higher value of moderator. This shows that the relationship opportunity based female entrepreneurship and competitiveness score is significant at mean and higher value of business environment.

Table: 4

Effect size of the business prospect on the relation between opportunity based female entrepreneurship and competitiveness score

\begin{tabular}{|c|c|}
\hline $\begin{array}{c}\text { Mean-Centered Value of the } \\
\text { cultural and social norms }\end{array}$ & $\begin{array}{c}\text { Effect Size of Moderator on relation between } \\
\text { opportunity based female entrepreneurship and } \\
\text { competitiveness score }\end{array}$ \\
\hline-9.3607 & 0.0038 \\
\hline 0 & $0.0123^{* *}$ \\
\hline 9.3607 & $0.0208^{*}$ \\
\hline
\end{tabular}

$* * * \mathrm{p}<0.01, * * \mathrm{p}<0.05, * \mathrm{p}<0.1$, f $\mathrm{p}<0.15$

Similar results are obtained from the slope test. The slope of the line based on the regression equation represent the relationship between opportunity based female entrepreneurship and competitiveness score. Slope of this line gradually increases as we move from lower to higher value of business environment. This shows that our Hypothesis No 2 is proved. 


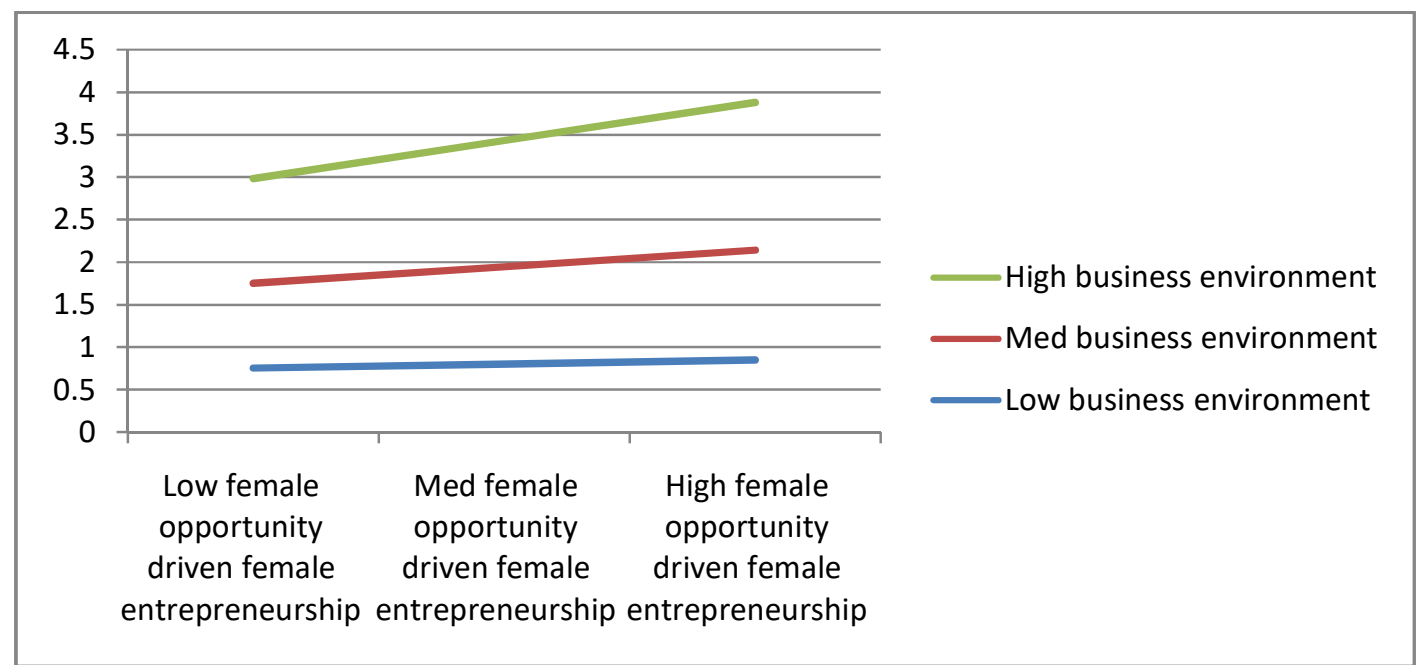

Figure 2: Moderating role of business environment on the relationship between opportunity based female entrepreneurship and competitiveness score

Table No 5 shows the results of mediating role of competitiveness score on relationship between opportunity driven female entrepreneurship and log GDP per capita. According to Model No 1 of the Table No 5, outcome (log GDP per capita) is positively associated with female opportunity driven entrepreneurship, and this relation is statistically significant. However, the relationship between dependent and independent variables was very weak as the value of $\mathrm{R}^{2}$ was very low. Furthermore, this relation is significant at $\mathrm{p}<0.05$. This shows that our Hypothesis No 3 is proved. This finding differs from the results of Korez-Vide and Tominc (2016) who, in the context of Central and Eastern European states of the European Union, have found an insignificant relationship between early stage entrepreneurship level and growth of GDP.

Table: 5

Mediating role of competitiveness score on relationship between opportunity driven female entrepreneurship and $\log$ GDP per capita

\begin{tabular}{|l|c|c|}
\hline Name of Variable & $\mathbf{1}$ & $\mathbf{2}$ \\
\hline Opportunity driven female & $0.008^{* *}$ & -0.001 \\
entrepreneurship & $(0.004)$ & $(0.003)$ \\
\hline Competitiveness score & & $0.424^{* *}$ \\
& & $(0.070)$ \\
\hline Constant & $3.745^{\cdots \cdots}$ & $2.453^{* \cdots}$ \\
& $(0.246)$ & $(0.294)$ \\
\hline Value of $\mathbf{R}^{2}$ & $\mathbf{0 . 1 0 4}^{* *}$ & $\mathbf{0 . 4 7 0}$ \\
\hline
\end{tabular}

Note: Values represent un-standardized coefficients while those in parenthesis are standard deviation of un-standardized coefficients $* * * \mathrm{p}<0.01, * * \mathrm{p}<0.05, * \mathrm{p}<0.1$, f $\mathrm{p}<0.15$. 
However, the introduction of competitiveness score as a mediator renders the female opportunity driven entrepreneurship statistically insignificant while the mediating variable itself remains significant. This partially supports the results of Kordalska and Olczyk (2016) who have found that Global Competitiveness Index can predict growth of low and high income level countries. This shows that competitiveness score mediates the relationship between female opportunity driven entrepreneurship and economic growth of the country. Hence, our fourth hypothesis is also proved.

\section{Discussion}

After reviewing the factors which positively or negatively affect success of entrepreneurship, Garcia \& Capitan (2016) believe that there are three analytical perspectives found in the literature. First is the Schumpeterian perspective who insists on combining economic conditions and functioning of market to be predictive of entrepreneurial activities. Then there is psychological perspective presented by McClelland which focuses on the individual attributes of the entrepreneur such as risk aversion, novelty and innovation, long term planning and accepting of responsibility for actions. The third stream of research emphasises on the role of contextual factors, such as social capital, social networks, working conditions, business environment etc, in the development of entrepreneurship. Based on these previous lines of enquiries, this study focuses on the impact of female entrepreneurial activities and a supportive business environment in enhancing national competitiveness and boasting economic growth of a country.

First of all, this study using data from Global Entrepreneurship Monitor (GEM) and Global Competitiveness Index (CGI) proves existence of relationship between opportunity driven entrepreneurship among women and national competitiveness level. This shows that different composite measures such as GEM and CGI based on macroeconomic indicators have made it easier to understand the relationship between entrepreneurial activities and national competitiveness level (Goncalves et al., 2015). This finding confirms that women entrepreneurs add diversity to business market. Their creativity boasts innovation and competition in the business which encourages new entrants and improves performance of existing firms. These findings are aligned with the research of Verheul, Stel and Thurik (2004), who in their study of 29 countries note that countries having higher entrepreneurial level show more participation from female entrepreneurs.

This study also shows that the relationship between opportunity driven entrepreneurship among women and national competitiveness level is moderated by overall business environment of the country. This supports Busenitz, Gomez and Spencer (2000) who assert that variation in the level of entrepreneurial activities can be explained with the 
help of institutions which can both guide and constraint business activities as well as national economic growth. Paenicny et al., (2014) concluded that environmental barrier and difficulties in financing are two important factors which can inhibit growth of a country. In some countries, gender discrimination coupled with weak institutions can discourage women starting their own business (Marques, 2017).

This study shows that opportunity driven female entrepreneurship is positively and significantly related with economic growth. This confirms result of Acs (2006) who have found a positive relationship between ratio opportunity and necessity entrepreneurship and economic growth. Finally, this study also proves that the relationship between opportunity driven female entrepreneurship and economic growth is mediated by national competitiveness level. This supports claim of Schumpeter and other scholars who regard that entrepreneurs intensify competition between firms which boasts economic development. The growth of dynamic and innovative enterprises can be used as an indicator to gauge the economic growth of a country (Paenicny et al., 2014). National competitiveness is important for both developing and developed countries alike and policy makers are focusing on this issue (Kordalska \& Olczyk, 2016). On the other hand, obstacles in the entry of women in entrepreneurship can have detrimental consequence on innovation, competition and economic growth of country (Kobeissi, 2010).

\section{Recommendations}

Results of this study show the importance of business start-ups by females which is quickly becoming a worldwide phenomenon. As the number of women launching their own business is steadily increasing throughout the world, and it is exploiting an untapped source of economic growth (Hattab, 2012). Governments are focusing on developing policies use women entrepreneurs in achieving rapid economic growth. These policies are directed at attracting female entrepreneurs who have lower rate to start a business as compared to men (Rubio-Bañón \& Esteban-Lloret, 2016).

However, more efforts are still required by the governments to encourage participation of women in economic activities. Due to poor social position, women have less bargaining power to negotiate with suppliers and customers as well as dealing with government officials. It is imperative that policy makers should focus on creating a supportive policy for women entrepreneurs. Entrepreneurial policy is defined by Stevenson and Lundstrom (2001) as "measures taken to stimulate more entrepreneurial behaviour in a region or a country." These policies can range from improving input factors associated with demand and supply of entrepreneurial activities, preferences and decision making process of entrepreneurs (Terjesen, Bosma \& Stam, 2016). Such policies will enhance female business start-ups and promote women owned business by providing an equal playing field to both male and female entrepreneurs. 
It is also equally important for government to develop institution supportive for female entrepreneurial activities. Financial institutes and their credit policies play an important role in the growth of entrepreneurship especially in low income level countries. Some believe that the unfavourable economic policies related to loan are prime hurdle to the growth of female businesses. On the other hand, availability of credit to women will result in poverty reduction and economic growth (Lock \& Smith, 2016). Therefore, governments should work on developing supportive credit policies (Galindo \& Mendez, 2014). This ensures availability of credit which can prevent female owned firms from performing below par due to under-capitalization. Thus, a better financial system and regulatory environment in a country can foster creation of new business entities.

\section{Conclusions}

According to Schumpeter (1947, cited in Galindo \& Mendez, 2014) "we should recognize the importance of, and systematically inquire into, entrepreneurship as a factor of economic growth". With this purpose in mind, this study provides a framework on how female entrepreneurship can lead to economic growth. Economic growth is, in fact, a journey from developing country to advanced ones and it can be used a bridge to gap the difference from developed countries (Kowal \& Roztocki, 2013). In order to achieve rapid economic development, it is imperative to create opportunities and supportive environment for female entrepreneurs because the overall business environment and the growth orientation of the entrepreneurs have significant influence on the growth of a dynamic organization as well as the country (Paenicny et al., 2014). Female entrepreneurs can increase the competiveness level in a country through creativity and innovation which boasts economic performance.

Many governments around the world have realized the importance of developing informal business sectors (Lock \& Smith, 2016). Since female entrepreneurs mostly work in informal sectors, therefore, attention is given to encourage women to start their own business (McGowan et al., 2012). A special focus on generating more opportunities for female entrepreneurs will result in financial independence, social empowerment, and economic development of women. Some aspects of female entrepreneurship are tied up with institutional system of a country (Minniti, 2010). Therefore, governmental policies should enables entrepreneur to legally register their corporation easily and protect them from investment risks (Busenitz, Gomez \& Spencer, 2000). This will lead to the creation of new business ventures that can further economic growth as they support competition and innovation.

\section{Reference}

Acs, Z. (2006). How is entrepreneurship good for economic growth? Innovations, vol.1:1, pp.97-107. 
Acs, Z. J., Bardasi, E., Estrin, S. \& Svejnar, J. (2011). Introduction to Special Issue of Small Business Economics on Female Entrepreneurship in Developed and Developing Economies. Small Business Economics, vol.37:4, pp.393-396.

Adom, K. \& Asare-Yeboa, I. T. (2016). An Evaluation of Human Capital Theory and Female Entrepreneurship in Sub-Sahara Africa: Some Evidence from Ghana. International Journal of Gender and Entrepreneurship, vol.8:4, pp.402-423.

Ahl, H. (2006). Why Research on Women Entrepreneurs Needs New Directions. Entrepreneurship Theory and Practice, vol.30:5, pp.595-621.

Aidis, R., Welter, F., Smallbone, D. \& Isakova, N. (2007). Female Entrepreneurship in Transition Economies: The Case of Lithuania and Ukraine. Feminist Economics, vol.13:2, pp.157-183.

Albotmeh, S. \& Irsheid, S. (2013). Barriers to Female Labour Market Participation and Entrepreneurship in the Occupied Palestinian Territory. Palestine: Center for Development Studies, Birzeit University.

Armour, J. \& Cumming, D. (2008). Bankruptcy Law and Entrepreneurship. American Law and Economics Review, vol.10:2, pp.303-350.

Bates, T., Jackson III, W. E. \& Johnson Jr, J. H. (2007). Advancing Research on Minority Entrepreneurship. The Annals of the American Academy of Political and Social Science, vol.613:1, pp.10-17.

Baughn, C. C., Chua, B. L. \& Neupert, K. E. (2006). The Normative Context for Women's Participation in Entrepreneurship: A Multicountry Study. Entrepreneurship Theory and Practice, vol.30:5, pp.687-708.

Baumol, W. J. (1990). Entrepreneurship: Productive, Unproductive, and Destructive. Journal of Political Economy, vol.98:5, pp.893-921.

Brush, C. G., Carter, N. M., Gatewood, E. J., Greene, P. G. \& Hart, M. M. (2006). Introduction: the Diana Project International. In C. G. Brush, N. M. Carter, E. J. Gatewood, P. G. Greene, \& M. M. Hart (Eds.), Growth-oriented Women Entrepreneurs and their Businesses: A Global Perspective, Edward Elgar, Cheltenham (pp. 3-22). Cheltenham and Northampton, MA: Edward Elgar. 
Brush, C. G. \& Cooper, S. Y. (2012). Female Entrepreneurship and Economic Development: An International Perspective. Entrepreneurship \& Regional Development, vol.24:1-2, pp.1-6.

Brush, C. G., De Bruin, A. \& Welter, F. (2009). A Gender-Aware Framework for Women's Entrepreneurship. International Journal of Gender and Entrepreneurship, vol.1:1, pp.8-24.

Busenitz, L. W., Gomez, C. \& Spencer, J. W. (2000). Country Institutional Profiles: Unlocking Entrepreneurial Phenomena. Academy of Management Journal, vol.43:5, pp.994-1003.

Carree, M. A. \& Thurik, A. R. (2003). The Impact of Entrepreneurship on Economic Growth. In Z. J. Acs \& D. B. Audretsch (Eds.), Handbook of Entrepreneurship Research (pp. 437-471): Springer.

Chamlee-Wright, E. (2002). The Cultural Foundations of Economic Development: Urban Female Entrepreneurship in Ghana. London and New York: Routledge.

Coleman, S. \& Carsky, M. (1996). Financing Small Business: Strategies Employed by Women Entrepreneurs. The Journal of Applied Management and Entrepreneurship, vol.3:1, pp.28-42.

Colombelli, A., Krafft, J. \& Vivarelli, M. (2016). Entrepreneurship and Innovation: New Entries, Survival, Growth: Groupe de REcherche en Droit, Economie, Gestion (GREDEG CNRS), University of Nice Sophia Antipolis.

Danish, A. Y. \& Smith, H. L. (2012). Female Entrepreneurship in Saudi Arabia: Opportunities and Challenges. International Journal of Gender and Entrepreneurship, vol.4:3, pp.216-235.

Davidsson, P., \& Honig, B. (2003). The Role of Social and Human Capital among Nascent Entrepreneurs. Journal of Business Venturing, vol.18:3, pp.301-331.

Dejardin, M. (2011). Linking Net Entry to Regional Economic Growth. Small Business Economics, vol.36:4, pp.443-460.

Estrin, S. \& Mickiewicz, T. (2011). Institutions and Female Entrepreneurship. Small Business Economics, vol.37:4, p.397. 
Galindo, M.-Á. \& Mendez, M. T. (2014). Entrepreneurship, Economic Growth, and Innovation: Are Feedback Effects at Work? Journal of Business Research, vol.67:5, pp.825-829.

Gallant, M., Majumdar, S. \& Varadarajan, D. (2010). Outlook of Female Students Towards Entrepreneurship: An Analysis of a Selection of Business Students in Dubai. Education, Business and Society: Contemporary Middle Eastern Issues, vol.3:3, pp.218-230.

Garcia, P. O. \& Capitan, Á. O. (2016). Elements that Contribute to Boost Female Entrepreneurship: A Prospective Analysis. Suma de Negocios, vol.7:15, pp.54-60.

Ghani, E., Kerr, W. R. \& O' connell, S. D. (2013). Local Industrial Structures and Female Entrepreneurship in India. Journal of Economic Geography, vol.13:6, pp.929-964.

Goltz, S., Buche, M. W. \& Pathak, S. (2015). Political Empowerment, Rule of Law, and Women's Entry into Entrepreneurship. Journal of Small Business Management, vol.53:3, pp.605-626.

Goncalves, M. P., Lima, A. O., Fontenele, R. E. S. \& Peter, M. d. G. A. (2015). Entrepreneurship, Competitiveness and Economic Growth of Brazilian Regions. Paper Presented at the XXXIX Meeting of ANPAD -EnANPAD 2015, Belo Horizonte, Brazil.

Gries, T. \& Naudé, W. (2011). Entrepreneurship and Human Development: A Capability Approach. Journal of Public Economics, vol.95:3, pp.216-224.

Hattab, H. (2012). Towards Understanding Female Entrepreneurship in Middle Eastern and North African Countries: A Cross-Country Comparison of Female Entrepreneurship. Education, Business and Society: Contemporary Middle Eastern Issues, vol.5:3, pp.171-186.

Hayton, J. C., George, G. \& Zahra, S. A. (2002). National Culture and Entrepreneurship: A Review of Behavioral Research. Entrepreneurship Theory and Practice, vol.26:4, p.33.

Hilman, H. \& Warokka, A. (2011). The Effects of Entrepreneurship, Competitiveness, and Technology Innovation on Growth: A Case of ASEAN Economic Development. Jurnal Ekonom, vol.14:3, pp.119-127. 
Jennings, J. E., \& Brush, C. G. (2013). Research on Women Entrepreneurs: Challenges to (and from) the Broader Entrepreneurship Literature? Academy of Management Annals, vol.7:1, pp.663-715.

Kobeissi, N. (2010). Gender factors and female entrepreneurship: International evidence and policy implications. Journal of International Entrepreneurship, vol.8:1, pp.1-35.

Kordalska, A., \& Olczyk, M. (2016). Global Competitiveness and Economic Growth: A One-Way or Two-Way Relationship? Equilibrium. Quarterly Journal of Economics and Economic Policy, vol.11:1, pp.121-142.

Korez-Vide, R., \& Tominc, P. (2016). Competitiveness, Entrepreneurship and Economic. Growth Competitiveness of CEE Economies and Businesses (pp. 25-44): Springer.

Kostova, T. (1997). Country institutional profiles: Concept and measurement. Paper presented at the Academy of Management proceedings.

Kowal, J., \& Roztocki, N. (2013). Information and communication technology management for global competitiveness and economic growth in emerging economies. The Electronic Journal of Information Systems in Developing Countries, vol.57, pp.1-12.

Llussa, F. (2009). Financial Development, Gender and Entrepreneurship. Massachusetts Institute of Technology Engineering Systems Division.

Lock, R., \& Smith, H. L. (2016). The impact of female entrepreneurship on economic growth in Kenya. International Journal of Gender and Entrepreneurship, vol.8:1, pp.90-96.

Marques, H. (2017). Gender, Entrepreneurship and Development: Which Policies Matter? Development Policy Review, vol.35:2, pp.197-228.

McGowan, P., Redeker, C. L., Cooper, S. Y. \& Greenan, K. (2012). Female Entrepreneurship and the Management of Business and Domestic Roles: Motivations, Expectations and Realities. Entrepreneurship \& Regional Development, vol.24:1-2, pp.53-72.

Minniti, M. (2010). Female Entrepreneurship and Economic Activity. The European Journal of Development Research, vol.22:3, pp.294-312. 
Minniti, M., \& Nardone, C. (2007). Being in Someone else's Shoes: The Role of Gender in Nascent Entrepreneurship. Small Business Economics, vol.28:2, pp.223-238.

Morris, M. H., Miyasaki, N. N., Watters, C. E., \& Coombes, S. M. (2006). The Dilemma of Growth: Understanding Venture Size Choices of Women Entrepreneurs. Journal of Small Business Management, vol.44:2, pp.221-244.

Naguib, R. \& Jamali, D. (2015). Female Entrepreneurship in the UAE: A Multi-Level Integrative Lens. Gender in Management: An International Journal, vol.30:2, pp.135-161.

Nguyen, C., Frederick, H. \& Nguyen, H. (2014). Female Entrepreneurship in Rural Vietnam: An Exploratory Study. International Journal of Gender and Entrepreneurship, vol.6:1, pp.50-67.

Noguera, M., Alvarez, C., Merigó, J. M. \& Urbano, D. (2015). Determinants of Female Entrepreneurship in Spain: An Institutional Approach. Computational and Mathematical Organization Theory, vol.21:4, pp.341-355.

North, D. C. (1990). Institutions, Institutional Change and Economic Performance: Cambridge University Press.

Okah-Efogo, F. \& Timba, G. T. (2015). Female Entrepreneurship and Growth in Cameroon. African Journal of Economic and Management Studies, vol.6:1, pp.107-119.

Paenicny, V., Jakopin, E., Vukcevic, Z. \& Coric, G. (2014). Dynamic EntrepreneurshipGenerator of Sustainable Economic Growth and Competitiveness. Management: Journal of Contemporary Management Issues, vol.19:1, pp.61-92.

Palanivelu, V. \& Jahan, M. R. (2014). Women Entrepreneurship in the Context of Gender Competitiveness, Opportunities, and Hurdles. Paper presented at the International Conference on Arts, Economics and Management (ICAEM'14).

Petrariu, I. R., Bumbac, R. \& Ciobanu, R. (2013). Innovation: A Path to Competitiveness and Economic Growth. The Case of CEE Countries. Theoretical \& Applied Economics, vol.20:5.

Poggesi, S., Mari, M. \& De Vita, L. (2016). What's New in Female Entrepreneurship Research? Answers from the Literature. International Entrepreneurship and Management Journal, vol.12:3, pp.735-764. 
Porter, M. E. (1990). The Competitive Advantage of Nations. Harvard Business Review, vol.68:2, pp.73-93.

Pulido, D. U., Jiménez, E. F. \& i Noguera, M. N. (2014). Female Social Entrepreneurship and Socio-Cultural Context: An International Analysis. Revista de Estudios Empresariales. Segunda Época(2).

Ramadani, V., Rexhepi, G., Abazi-Alili, H., Beqiri, B. \& Thaçi, A. (2015). A Look at Female Entrepreneurship in Kosovo: An Exploratory Study. Journal of Enterprising Communities: People and Places in the Global Economy, vol.9:3, pp.277-294.

Rubio-Bañón, A. \& Esteban-Lloret, N. (2016). Cultural Factors and Gender Role in Female Entrepreneurship. Suma de Negocios, vol.7:15, pp.9-17.

Sara, C. \& Peter, R. (1998). The Financing of Male-and Female-Owned Businesses. Entrepreneurship \& Regional Development, vol.10:3, pp.225-242.

Sarfaraz, L., Faghih, N. \& Majd, A. A. (2014). The Relationship between Women Entrepreneurship and Gender Equality. Journal of Global Entrepreneurship Research, vol.4:1, p.6.

Schumpeter, J. A. (1934). The Theory of Economic Development. Cambridge: Harvard University Press.

Schumpeter, J. A. (1947). Theoretical Problems of Economic Growth. The Journal of Economic History, vol.7:S1, pp.1-9.

Schwab, K. \& Sala-i-Martin, X. (2015). World Economic Forum's Global Competitiveness Report, 2014-2015 Retrived from http://www.weforum.org. (28.02.2015).

Shane, S. \& Venkataraman, S. (2000). The Promise of Entrepreneurship as a Field of Research. Academy of Management Review, vol.25:1, pp.217-226.

Stel, A. V., Carree, M. \& Thurik, R. (2005). The Effect of Entrepreneurial Activity on National Economic Growth. Small Business Economics, vol.24:3, pp.311-321.

Stevenson, L. \& Lundstrom, A. (2001). Patterns and Trends in Entrepreneurship/SME Policy and Practice in ten Economies (Vol. 3): Swedish Foundation for Small Business Research Stockholm. 
Terjesen, S. \& Amoros, J. E. (2010). Female Entrepreneurship in Latin America and the Caribbean: Characteristics, Drivers and Relationship to Economic Development. The European Journal of Development Research, vol.22:3, pp.313-330.

Terjesen, S., Bosma, N. \& Stam, E. (2016). Advancing Public Policy for High-Growth, Female and Social Entrepreneurs. Public Administration Review, vol.76:2, pp.230-239.

Terrell, K. \& Troilo, M. (2010). Values and Female Entrepreneurship. International Journal of Gender and Entrepreneurship, vol.2:3, pp.260-286.

Verheul, I., Stel, A. V. \& Thurik, A. R. (2004). Explaining Female and Male Entrepreneurship Across 29 Countries: Papers on Entrepreneurship, Growth and Public Policy.

Verheul, I., Stel, A. V. \& Thurik, R. (2006). Explaining Female and Male Entrepreneurship at the Country Level. Entrepreneurship and Regional Development, vol.18:2, pp.151-183.

Welter, F. (2004). The Environment for Female Entrepreneurship in Germany. Journal of Small Business and Enterprise Development, vol.11:2, pp.212-221.

Wennekers, S. \& Thurik, R. (1999). Linking Entrepreneurship and Economic Growth. Small Business Economics, vol.13:1, pp.27-56.

Ansar Waseem is Ph.D Scholar in the School of Business \& Economics, University of Management \& Technology, Lahore, Pakistan. 